\title{
EFFECTS OF USING DDGS AND AVIZYME ENZYME IN THE BROILER DIETS ON SOME PHYSIOLOGICAL RESPONSES
}

\author{
Kawsar A. Ghaly*; Attiat H. El-Bogdady; S. A. Abd El-Latif; and A. S. Abd El- \\ Hameed
}

Anim. Prod. Dep., Fac. of Agric., Minia Uni., El-Minia, Egypt

*Corresponding author: kawsar Ghaly; Email: kawsarghaly@ yahoo.com

Received:10/04/2017

Accepted:25/042017

\begin{abstract}
This experiment aimed to study the effect of using distillers dried grains with soluble (DDGS) at different levels $(0,5,10,15 \%)$ treated with or without enzyme (avizyme1500) at level 0 and $1 \mathrm{~g} / \mathrm{kg}$ diet on some immunological and physiological responses of broiler chicks. Two hundred and sixty five, Arbor acres unsexed broiler day-old chicks, were randomly divided into eight groups with 32 birds per each. The sequence of the eight dietary treatments were as follow: T1- Basal diet (without DDGS or enzyme); T2, T3 and T4- Basal diet contains 5, 10 and 15\% DDGS without enzyme; T5, T6, T7 and T8- Basal diet contain $0,5,10,15 \%$ DDGS with enzyme. The results showed that blood proteins for birds fed dietary DDGS at different levels significantly $(\mathrm{p}<0.01)$ increased than those fed control diet. The means of total lipids, triglyceride, cholesterol, AST and ALT in the broilers fed dietary DDGS $(\mathrm{p}<0.01)$ differed, while creatinine value was insignificantly affected. The means of AST values for broilers fed the diet containing enzyme significantly $(p<0.01)$ decreased, while ALT level was not affected. Similarly, the means of $\mathrm{T}_{4}$ hormone concentration for broiler fed diet with adding enzyme significantly $(\mathrm{p}<0.01)$ reduced, while $\mathrm{T}_{3}$ insignificantly reduced compared with control diet. The mean PCV\% $(\mathrm{p}<0.01)$ increased while, $\mathrm{Hb}$ reduced significantly $(\mathrm{p}<0.01)$ compared with control diet while, no significant differences were detected in RBC's and WBC's counts.

From the present results it can be concluded that using grade levels (5, 10 and 15\%) of DDGS in broiler diets as untraditional ingredient (as a replacement of corn and soybean ingredients of diet) led to improve the physiological and immunological responses.
\end{abstract}

Keywords: Broiler chicks - DDGS and avizyme enzyme - Physiological responses. 
Kawsar A. Ghaly et al.

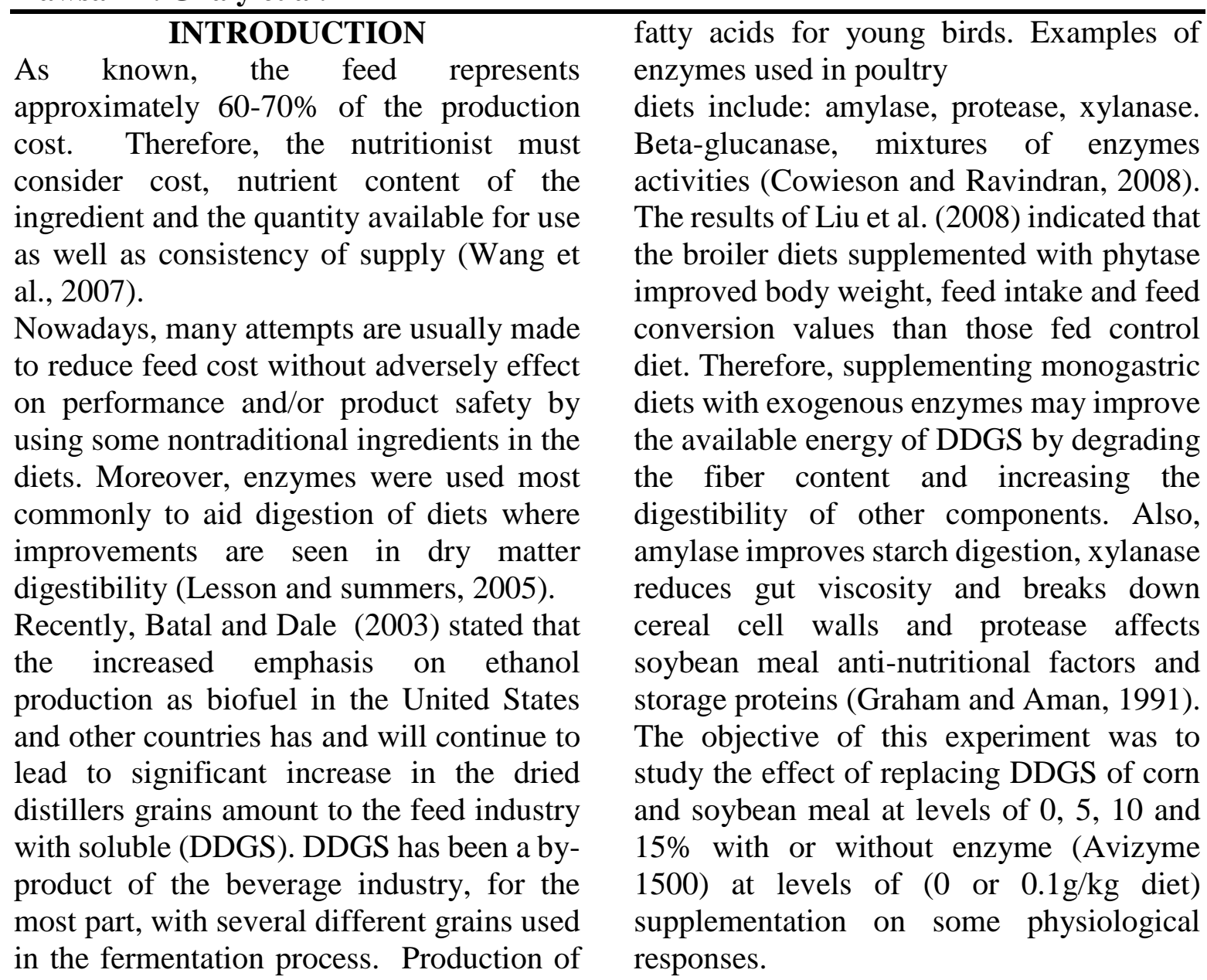
ethanol from $100 \mathrm{~kg}$ of corn using the drymilling method produces approximately $34.4 \mathrm{~kg}$ of ethanol, $34.0 \mathrm{~kg}$ of carbon dioxide and $31.6 \mathrm{~kg}$ of distillers dried grains with soluble (Renewable Fuels Association, 2005). Distillers dried grains with soluble are higher in non-starch polysaccharides (NSP), crude protein (CP), crude fat, and minerals than the parent grain. However, monogastric do not digest feedstuffs high in NSP efficiently.

Enzymes are now being manufactured specifically for feed use, and can be broadly categorized as carbohydrates, proteinases and lipases. Increasing the digestibility of various carbohydrate fractions of cereals and plant proteins has received most attention, although there is growing interest in potential for improving digestibility of both plant and animal proteins, and saturated

\section{MATERIALS AND METHODS}

This experiment was carried out at the Poultry Farm, Faculty of Agriculture, Minia University, Egypt. It aimed to study the effect of using dried distillers grains with soluble (DDGS) at different levels (0, 5, 10 and $15 \%)$ treated without or with enzyme (avizyme 1500) at level 0 and $1 \mathrm{~g} / \mathrm{kg}$ diet on some physiological and immunological responses of broiler chicks. Two hundred and sixty five unsexed, Arbor Acres broiler chicks, one day old were randomly distributed into 8 treatment groups with 32 chick per each i.e. ( 8 group's $\times 4$ replicates $\times 8$ chicks). The birds were housed in battery cages with dimensions ( 1 m length $\times 0.4 \mathrm{~m}$ wide $\times 0.6 \mathrm{~m}$ height). The experimental diets and fresh tab water were available adlibitum during the experimental period. All chicks were kept under similar managerial and hygienic conditions. They were reared 
at $32^{\circ} \mathrm{C}$ during the first week and gradually decrease untilabout $24^{\circ} \mathrm{C}$ at the $4^{\text {th }}$ week up to the end of the experiment ( 6 weeks of age). All chicks were daily exposed 23 lighting hours thorough the experimental period.

The experimental period was divided into two feeding phases, starter period from 1-21 days of age then, they were switched to finisher period from 22-42 days of age. The basal experimental diet had 23 and $20 \%$ crude protein and 3100 and $3200 \mathrm{Kcal}$ $\mathrm{ME} / \mathrm{kg}$ diet for the starter and finisher diet, respectively. Experimental diets were formulated to meet the nutrients requirements of the broiler chicks according NRC (1994). Four levels of dried distillers grains with soluble (DDGS) and two levels of Avizyme 1500 were studied i.e. $4 \times 2$ factorial design. The DDGS levels were 0 , 5,10 and $15 \%$ as substitution of soybean meal and corn in broiler chick diets during starter and finisher periods. While, enzyme levels were 0 and $1 \mathrm{~g} / \mathrm{kg}$ diet. The Avizyme $1500 \AA$ contained $600 \mathrm{U} / \mathrm{g}$ endo- 1,4 beta xylanase, $1600 \mathrm{U} / \mathrm{g}$ alpha amylase and 4000 $\mathrm{U} / \mathrm{g}$ protease.

The experimental diets and the chemical composition are presented in Table (1).

However, the composition and analysis of DDGS, soybean meal and yellow corn are presented in Table (2).

The sequence of the eight dietary treatments was as follow:-

1- Basal diet without DDGS or enzyme (T1).

2- Basal diet contains 5\% DDGS without enzyme (T2).

3- Basal diet contains 10\% DDGS without enzyme (T3).

4- Basal diet contains 15\% DDGS without enzyme (T4).

5- Basal diet with enzyme (T5).

6- Basal diet contains 5\% DDGS with enzyme (T6).

7- Basal diet contains 10\% DDGS with enzyme (T7).
8- Basal diet contains 15\% DDGS with enzyme (T8).

At the end of experiment (6 weeks), 32 chicks I (4 birds per treatment) were randomly taken, weighted and slaughtered after 12 hour of fasting, 32 blood samples were collected and divided into two parts, the first part was put in heparinized tube (2.25 $\mu$ heparin / $5 \mathrm{ml}$ blood) for the blood hematology and second sample was put in non-heparinized tube and centrifuged for 15 minutes at $3000 \mathrm{rpm}$ to separate serum which stored at deep freezer $\left(-20^{\circ} \mathrm{C}\right)$ until biochemical measurements. Serum total protein and albumin concentrations were determined according to (Gornal et al., 1949; and Doumas et al., 1971) using commercial kits, while globulin concentration was determined by subtracting albumin from total protein. Serum glucose concentration was determined according to (Trinder, 1969). Glutamic-Pyruvic Transaminase (ALT) and Glutamic -Oxaloacetic Transaminase (AST) were determined according to (Reitman and Frankel, 1957). Serum total lipids, triglycerides and cholesterol were determined according to Zollner and Kirsch (1962), Fassati and Prencipe (1982) and Young (2001). Serum triiodothyronine (T3) and thyroxin (T4) concentrations were determined radioimmunoassay procedures according to Chopra et al. (1971) by using kits purchased from Diagnostic products corporation, United States (USA). T3/T4 ratio $=\mathrm{T} 3(\mathrm{ng} / \mathrm{mg}) / \mathrm{T} 4(\mathrm{ng} / \mathrm{mg})$.

\section{Hematological parameters:}

Total red blood count $\left(\mathrm{N} \times 10^{6}\right)$ : The total red blood (RBC's) and Packed Cell Volume (PCV \%) values were counted according to Daice and Lewis (1991). In addition calculation of the absolute values or the erythrocyte indices, namely mean corpuscular volume (MCV), mean corpuscular hemoglobin $(\mathrm{MCH})$ and mean corpuscular hemoglobin concentration (MCHC) were calculated according to Konuk (1975). 
Immunological parameters:

Total white blood cells count $\left(\mathrm{N} \times 10^{3}\right)$ : The WBC'S were counted according to Campbell (1995). The humoral immune response was determined according to Mcewan et al. (1970), Meguire et al. (1976) and Pfeiffer et al. (1977).

Statistical analysis: Statistical analysis was performed by analysis of variance (two way analysis), SAS Institute (2003) with the general liner model (GLM), while the significant mean differences were distinguished by Duncan's Multiple Range Test (Duncan, 1955). The statistical analysis was calculated using the following model:

$\mathrm{Y}_{\mathrm{ijk}}=\mu+\mathrm{T}_{\mathrm{i}}+\mathrm{E}_{\mathrm{j}}+\mathrm{T}_{\mathrm{i}} \mathrm{E}_{\mathrm{j}}+\mathrm{e}_{\mathrm{ijk}}$

Where: $Y_{\mathrm{ijk}}=$ Experiment observations.

$\mu=$ the overall mean.

$\mathrm{T}_{\mathrm{i}}=$ the effect of DDGS levels $(\mathrm{i}=1,2,3,4)$.

$E_{j}=$ Effect of enzyme level $(j=1,2)$.

$\mathrm{T}_{\mathrm{i}} \mathrm{E}_{\mathrm{j}}=$ Effect of interaction between DDGS and enzyme $(\mathrm{ij}=1 \ldots 8)$

$\mathrm{e}_{\mathrm{ijk}}=$ the experimental error.

\section{RESULTS AND DISCUSSION Effect of dietary treatments on serum biochemical studies:}

Data presented in Table 3, revealed that dietary DDGS in broiler diets at 0, 5, 10 and $15 \%$ levels recorded a highly significant $(\mathrm{p}<0.01)$ difference in total protein, albumin , globulin and glucose. The greatest significant $(\mathrm{p}<0.01)$ value of glucose was recorded for birds fed dietary $15 \%$ DDGS compared with other DDGS levels. The improvement in the blood glucose for broilers fed diet containing DDGS may be due to a valuable source of energy in the DDGS for broilers. These results agree with those of Olentine (1986) and Noll et al. (2003).The present results indicated that higher value of the total protein and globulin concentration were recorded in DDGs treated than those control diet without any significant

differences. These results are in agreement with the findings of El-Abd (2013) who reported that the highest plasma total protein and globulin concentrations for Japanese quail fed the diets containing DDGS with 50 and $100 \%$ than the control diet.

In the present study, it could be noticed that adding enzymes to broiler diet significantly reduced total protein and albumin, while adding enzyme reduce insignificantly globulin. The glucose level in the blood for the broilers fed the diet with adding avizyme 1500 enzyme to diet improved significantly than those of the control diet.

The means of total protein, albumin and glucose for broilers were highly significantly $(\mathrm{p}<0.01)$ affected by the interaction between dietary DDGS either with or without enzymes. The highest values of total protein treated groups could be attributed to increase of liver enzymes (AST and ALT) values than that of the control.Generally, the enhancement of glucose and total protein as a result of adding enzymes to broiler DDGS diet may be due to that Avizyme 1502 (AZ1502) is an enzyme product containing purified xylanase, amylase, and protease targeted toward markets in which corn- soybean meal (SBM) are the primary feedstuffs used in poultry diets. The findings of Chesson (2001) indicated that, the corn kernel contains $111 \mathrm{~g} / \mathrm{kg}$ of total NSP, of which 23 and $30 \%$ for both of arabinose and xylose. That report could warrant the use of exogenous enzymes to increase digestibility.

On the other hand, Yassein et al. (2004) showed that, turkey plasma total protein, albumin and globulin concentration were not differ significantly as birds fed barley based-diets supplemented with or without enzymes (optizyme-p5) $1 \mathrm{~kg} /$ ton.

The data presented in Table 3, revealed that the total lipids, triglyceride and cholesterol for broilers fed dietary DDGS at different levels were significantly ( $\mathrm{p} \geq 0.05)$ affected, while creatinine value was not affected. The highly significant $(\mathrm{p}<0.01)$ value oftotal 
lipid was recorded for birds fed dietary $5 \%$ DDGS compared to other DDGS levels. However, the highest $(\mathrm{p}<0.01)$ value of cholesterol was recorded for birds fed dietary $10 \%$ DDGS followed by $15 \%$ DDGS. It could be noticed that, the highest insignificant value of creatinine was recorded for birds fed dietary 10\% DDGS followed by $15 \%$ DDGS and control diet. As a result of adding avizyme 1500 in Table 3, it could be noticed that adding enzymes to broiler diet significantly $(\mathrm{p}<0.01)$ reduced total lipids and triglycerides while, the cholesterol level was increased $(\mathrm{p}<0.05)$. However, creatinine value was not affected. According to the interaction between DDGS levels and enzyme additions, there were significant $(p<0.01)$ differences between DDGS levels either with or without enzyme addition in total lipids and triglycerides values. While, cholesterol or creatinine values were not affected. These results agree with Zeweil et al. (2005), who stated that the plasma total lipids concentration in Japanese quails fed different levels of rice bran with or without Optizyme at level of $0.5 \mathrm{~g} / \mathrm{kg}$ feed were slightly differed than those of the control diet. Shalash et al. (2009) reported that the plasma cholesterol, lipids or creatinine content for broilers fed dietary $12 \%$ DDGS without or with enzyme were not affected than those of the control diet. Yassein et al. (2004) showed that, turkey plasma total lipids concentration was not differ significantly as birds fed barley baseddiets supplemented with or without enzymes (optizyme-p5) $1 \mathrm{~kg} /$ ton.

The data presented in Table 4 revealed that the birds fed dietary DDGS at different levels recorded highly significant $(p<0.01)$ differences in AST and ALT values. Generally, incorporating DDGS as a traditional ingredient to the broiler diet increased $(\mathrm{p}<0.01)$ AST and ALT at different levels compared to birds fed control diet. In the present study, adding enzymes to broiler diet insignificantly decreased ALT and significantly $(\mathrm{p}<0.01)$ reduced AST values. These findings are in agreement with those of Makled et al. (2005) who showed that, blood aspartate amino transferase; U/L was significantly increased as affected by adding Optizyme to rabbit's diet at 500 or $750 \mathrm{mg} / \mathrm{kg}$ diet. Referringto the effect of interaction between DDGS levels and enzyme additions, the results showed no significant differences between DDGS levels either with or without enzyme addition in AST and ALT values. The results indicated that, in spite of, enzyme addition, using dietary DDGS in broiler diets at different level 0, 5, 10 and $15 \%$ recorded a significant $(\mathrm{p}<0.05)$ difference in T3/T4 ratio while, no significant differences were detected in $\mathrm{T} 3$ and T4 values. Birds fed dietary 5\% DDGS recorded the best $(\mathrm{p}<0.05)$ value of $\mathrm{T} 3 / \mathrm{T} 4$ ratio followed by birds fed dietary $10 \%$ DDGS. Interaction between DDGS levels and avizyme 1500 additions, has a significant $(\mathrm{p}<0.05)$ difference in $\mathrm{T} 4$ and T3/T4 ratio among all dietary interaction, while, no significant $(\mathrm{p} \geq 0.05)$ difference was recorded in T3 values. Birds fed dietary 5\% DDGS without enzyme addition recorded the greatest $(\mathrm{p}<0.05)$ value of $\mathrm{T} 4$ followed by birds fed control diet without enzyme addition. The highest $(\mathrm{p}<0.05)$ value of T3/T4 ratio was recorded for birds fed dietary 5\% DDGS contributed with enzyme compared with all dietary DDGS levels either with or without enzyme. The results of Yukio Akiba et al. (1982) indicated that, no significant differences were observed in thyroxin (T4) levels among dietary treatments, but plasma triiodothyronine (T3) levels in hens fed 20\% DDGS diet was significantly lower than that of hens fed the basal diet. Zhang Shi-yuan et al. (2009) fed ducks on diets contained 0,5, 8 and 11\% DDGS. They concluded that, blood levels of T3 in three trial groups were significantly lower than that in the control group, while, blood $\mathrm{T} 4$ concentrations were significantly increased. 
The best proportion of DDGS in the broiler diets are 8 and $11 \%$, respectively.

\section{Effect of dietary treatments on some hematological parameters:}

The results in Table 5 showed significant differences between DDGS levels in RBC's, $\mathrm{PCV}, \mathrm{Hb}, \mathrm{MCH}$ and $\mathrm{MCHC}$, while, no significant difference was detected in MCV as a result of using. The lowest $(p<0.05)$ count of RBC's and $\mathrm{Hb}$ value were found forbroilers fed both of control diet and 10\% DDGS, respectively compared to other DDGS levels. Generally, birds fed dietary $15 \%$ DDGS recorded the highest $(\mathrm{p}<0.01)$ values of RBC's, PCV\%, $\mathrm{Hb}, \mathrm{MCH}$ and MCHC compared to other treatments. Birds fed $5 \%$ and $15 \%$ DDGS levels recorded significant $(\mathrm{p}<0.01)$ differences in $\mathrm{MCHC}$ compared to birds fed control diet and $15 \%$ DDGS. The increase in hemoglobin concentration could be attributed to the higher oxygen consumption associated with more hemoglobin saturation and dissociation rates (Yahav et al., 1998). Referring to the effect of adding avizyme, it could be noticed that adding enzyme to broiler diet significantly $(\mathrm{p}<0.01)$ increased $\mathrm{PCV}$ and $\mathrm{MCV}$, while $\mathrm{Hb}, \mathrm{MCH}$ and $\mathrm{MCHC}$ values were significantly reduced $(p<0.01)$ compared with control diet. No significant $(\mathrm{p} \geq 0.05)$ differences were detected as a result of adding enzyme to broiler diet in RBC's. These results agrees with Youssef et al. (2013) who indicated that the hemoglobin $(\mathrm{Hb})$ concentration was significantly increased for birds fed all DDGS treated compared to control group. Regarding to the interaction between DDGS levels and enzyme additions, it could be, found that, there is a significant $(\mathrm{p}<0.01)$ difference in $\mathrm{PCV} \%, \mathrm{Hb}, \mathrm{MCH}$ and $\mathrm{MCHC}$. While, no significant $(\mathrm{p} \geq 0.05)$ difference was found in RBC's and MCV values. In general, the highest $(p<0.01)$ values of $P C V$, $\mathrm{Hb}, \mathrm{MCH}$ as well as MCHC were recorded for birds fed dietary 15\% DDGS without enzyme addition as compared with other dietary treatments.

\section{Effect of dietary treatments on some immune parameters:}

The effect of dietary DDGS levels, enzymes addition and their interaction on some immune parameters such as total leukocytes (WBC's x $103 / \mathrm{mm} 3$ ) and total immune globulin ( $\mathrm{Ig}$ ) are presented in Table (5). There are a significant $(\mathrm{p}<0.01)$ difference between DDGS levels in total Ig. While, no significant difference was detected in WBC'S. The highest value $(\mathrm{p}<0.01)$ of total Ig was recorded for birds fed dietary $15 \%$ DDGS, while the lowest value $(\mathrm{p}<0.01)$ was obtained in birds fed control diet. It could be noticed that, adding enzyme to broiler diet significantly $(p<0.01)$ improved total Ig. However, birds fed dietary incorporated with enzyme had highest insignificant value in WBC's compared to birds control diet. According to the interaction between DDGS levels and enzyme additions, it could be, found that, there is a significant $(\mathrm{p}<0.01)$ difference in WBC's and total Ig among all dietary interaction treatments. The results showed that the highest value of WBC's were obtained in chicks fed dietary $10 \%$ DDGS without enzyme addition, followed by those fed dietary 5\% DDGS as compared with different dietary treatments. The total Ig for birds fed dietary $15 \%$ DDGS recorded the highest $(\mathrm{p}<0.01)$ value incorporated with enzyme compared with other dietary DDGS levels either with or without enzyme. The lowest ( $p \geq 0.05$ ) vales of WBC's and total Ig were noticed when birds fed control diet.

Barekatain et al. (2013) reported that adding DDGS to the diets improved $(\mathrm{p}<0.01)$ the IgA and $\mathrm{IgG}$ values at $13^{\text {th }}$ day but interacted with the disease challenge, reducing the concentration of $\operatorname{IgA}$ at 21 day and $\operatorname{IgM}$ at $35^{\text {th }}$ day in the infected birds. Zou1 et al. (2006) found that the broiler chicks fed on corn-soybean meal basal diets and supplemented with $\beta$-mannanase (Hemi 
cell) enzyme at $0,0.025,0.05$, and $0.075 \%$ levels, respectively. They indicated that, hemi cell significantly increased $(\mathrm{p}<0.05)$ the serum IgM concentration in 3- and 6-wkold broilers. The results of Ragy (2013) indicated that the antioxidant capacity for quail fed on corn-soybean meal based diets contained 0,10,15 and 20\% DDGS with or without enzymes significantly differed among treated than that of the control. It can be concluded that using gradually levels $(5$, 10 and $15 \%$ ) of DDGS in broiler diets improved the physiological and immunological responses. 
Kawsar A. Ghaly. et al.

Table (1): Composition, calculated and determined analysis of starter (1-21 days of age) and finisher (22-42 days of age) diets

\begin{tabular}{|c|c|c|c|c|c|c|c|c|}
\hline \multirow{3}{*}{ Ingredients } & \multicolumn{4}{|c|}{ Finisher } & \multicolumn{4}{|c|}{ Starter } \\
\hline & \multicolumn{8}{|c|}{ Levels of DDGS } \\
\hline & $0 \%$ & $5 \%$ & $10 \%$ & $15 \%$ & $0 \%$ & $5 \%$ & $10 \%$ & $15 \%$ \\
\hline Yellowcorn,ground & 52.17 & 49.62 & 46.83 & 44.29 & 60.50 & 57.63 & 55.08 & 52.50 \\
\hline Soybean 1 & 2.00 & 29.30 & 26.80 & 24.10 & 23.50 & 21.00 & 18.30 & 15.65 \\
\hline DDGS * & 0.00 & 5.00 & 10.00 & 15.00 & 0.00 & 5.00 & 10.00 & 15.00 \\
\hline Broilerconcentrate, $45 \%$ & 10.00 & 10.00 & 10.00 & 10.00 & 10.00 & 10.00 & 10.00 & 10.00 \\
\hline Cotton seed oil & 4.28 & 4.53 & 4.82 & 5.06 & 4.40 & 4.72 & 4.97 & 5.20 \\
\hline Lime & 0.80 & 0.80 & 0.80 & 0.80 & 0.85 & 0.90 & 0.90 & 0.90 \\
\hline Vit. Min. Premix $* *$ & 0.25 & 0.25 & 0.25 & 0.25 & 0.25 & 0.25 & 0.25 & 0.25 \\
\hline Salt, $\mathrm{NaCl}$ & 0.50 & 0.50 & 0.50 & 0.50 & 0.50 & 0.50 & 0.50 & 0.50 \\
\hline Total & 100 & 100 & 100 & 100 & 100 & 100 & 100 & 100 \\
\hline \multicolumn{9}{|l|}{ Calculated analysis } \\
\hline & 23.65 & 23.85 & 23.30 & 23.39 & 20.27 & 21.09 & 19.44 & 19.44 \\
\hline ME (Kcal /kg) & 3100 & 3100 & 3100 & 3100 & 3200 & 3200 & 3200 & 3200 \\
\hline Crude fiber, $\% * * *$ & 3.03 & 3.47 & 4.28 & 3.57 & 2.70 & 3.13 & 3.94 & 3.20 \\
\hline Calcium & 1.01 & 1.01 & 1.01 & 1.01 & 1.00 & 1.03 & 1.03 & 1.03 \\
\hline Available phosphorus & 0.65 & 0.67 & 0.68 & 0.70 & 0.62 & 0.64 & 0.65 & 0.66 \\
\hline Methionine and cysteine & 0.93 & 0.94 & 0.95 & 0.95 & 0.85 & 0.86 & 0.87 & 0.87 \\
\hline Lysine, \% & 1.37 & 1.32 & 1.28 & 1.23 & 1.16 & 1.12 & 1.07 & 1.02 \\
\hline
\end{tabular}

* Dried distillers grains with soluble

** Each $2.5 \mathrm{Kg}$ of vitamins and minerals mixture contains: Vitamin D3, $12000.000 \mathrm{IU}$; Vitamin E acetate, $10.000 \mathrm{mg}$; Vitamin K3, $2000 \mathrm{mg}$; Vitamin B1, $100 \mathrm{mg}$; Vitamin B2, $4000 \mathrm{mg}$; Vitamin B6, $1500 \mathrm{mg}$; Vitamin B12, $10 \mathrm{mg}$; pantothenic acid, $10.000 \mathrm{mg}$; nicotinic acid, $20.00 \mathrm{mg}$; Folic acid, $1000 \mathrm{mg}$; Biotin, $50 \mathrm{mg}$; chorine, $500 \mathrm{mg}$; Copper, 10.000; Iodine, $1000 \mathrm{mg}$; Iron, $300.00 \mathrm{mg}$; Manganese, $55.000 \mathrm{mg}$; Zinc, $55.000 \mathrm{mg}$; and Selenium, $100 \mathrm{mg}$.

$* * *$ Determined analysis

Table (2): Proximate analysis (\%) of dried distillers grains with soluble (DDGS), Yellow corn and Soybean meal

\begin{tabular}{|l|c|c|c|c|c|c|}
\hline Ingredients & $\begin{array}{c}\text { Dry } \\
\text { matter }\end{array}$ & $\begin{array}{c}\text { Organic } \\
\text { matter }\end{array}$ & Ash & $\begin{array}{c}\text { Crude } \\
\text { Protein }\end{array}$ & $\begin{array}{c}\text { Crude } \\
\text { fiber }\end{array}$ & $\begin{array}{c}\text { Ether } \\
\text { extract }\end{array}$ \\
\hline DDGS & 90.53 & 91.81 & 8.19 & 25.7 & 9.08 & 9.27 \\
Soybean meal & 89.2 & 94.1 & 5.9 & 43.21 & 6.7 & 0.95 \\
Yellow corn & 88.5 & 98.1 & 1.9 & 8.6 & 2.4 & 3.5 \\
\hline
\end{tabular}


Table (3): Effect of dried distillers grains with solubles (DDGS) levels, enzyme preparation and their interaction on total protein, albumin, globulin, total lipid, triglyceride, cholesterol and creatinine of broiler chicks

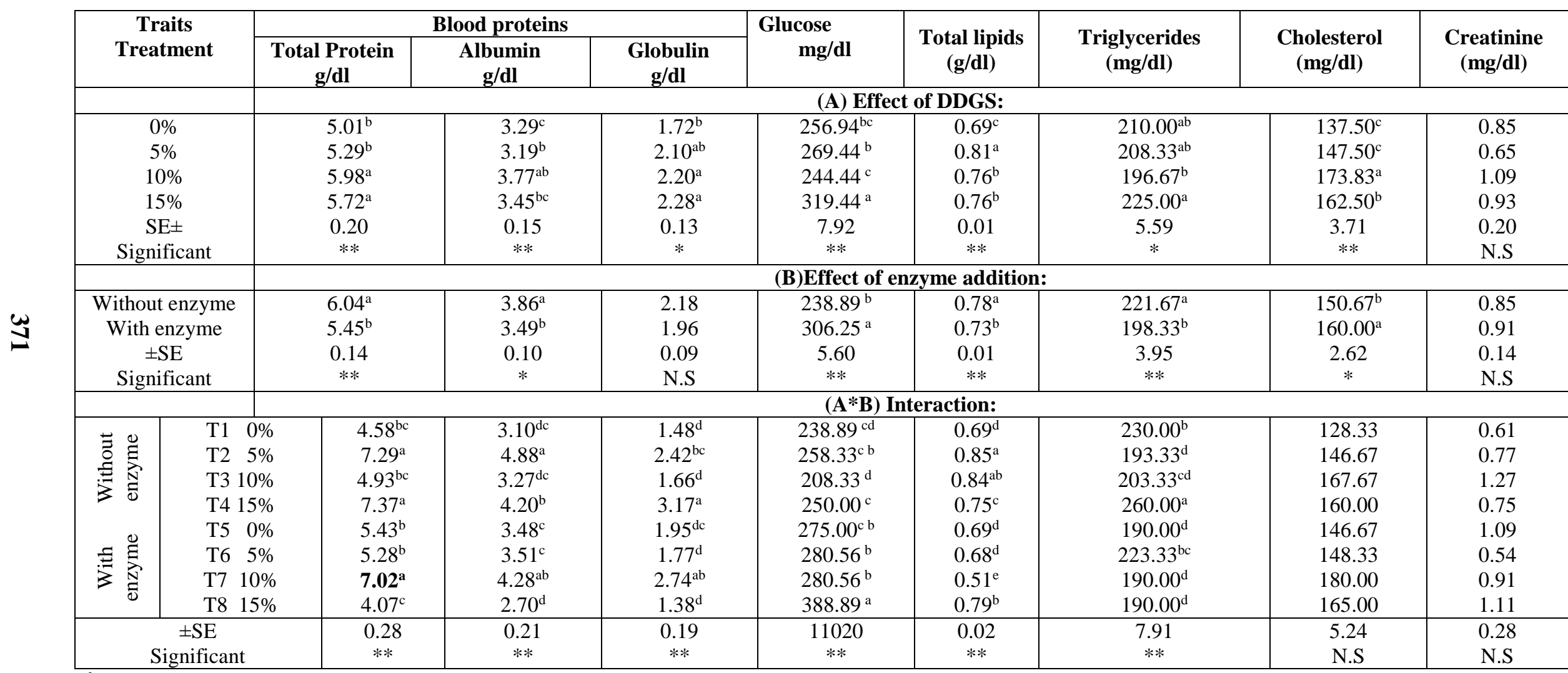

a, b,c,...etc Means in each column, within each item, bearing the same superscripts are significantly different $(\mathrm{p}<0.05)$. N.S not significantly different $(\mathrm{p} \geq 0.05)$.

(Means \pm SE). Avizyme 1500 enzyme at levels of 0 and $1 \mathrm{~g} / \mathrm{kg}$ diet. 
Table (4): Effect of dried distillers grains with soluble (DDGS) levels, enzyme preparation and their interaction on liver enzymes and thyroid hormones in broiler chicks

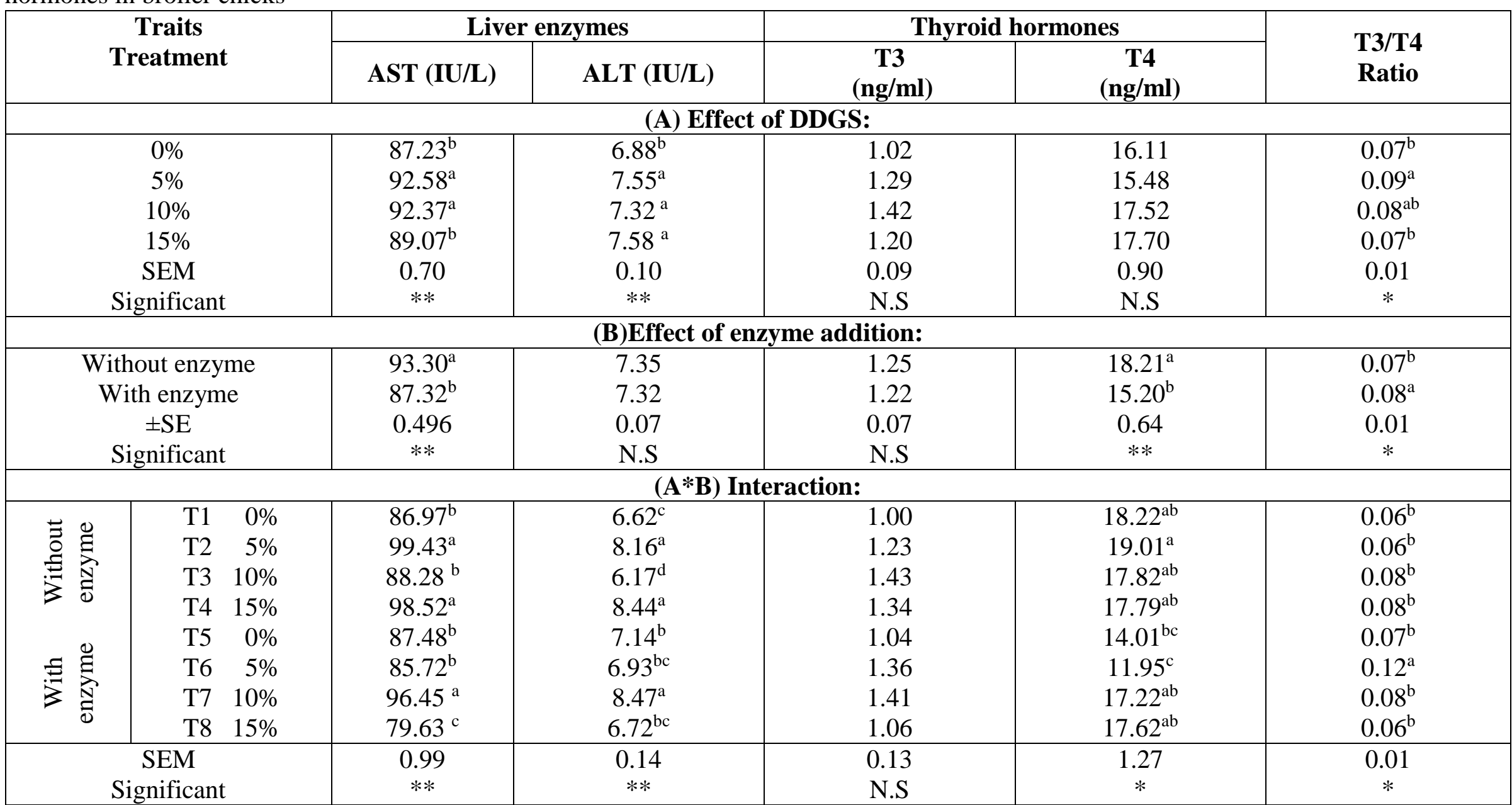

a, b,c,..etc Means in each column, within each item, bearing the same superscripts are significantly different ( $\mathrm{p}<0.05)$. N.S not significantly different ( $\mathrm{p} \geq 0.05)$. (Means \pm SE). Avizyme 1500 enzyme at levels of 0 and $1 \mathrm{~g} / \mathrm{kg}$ diet. 
Table (5): Effect of dried distillers grains with solubles (DDGS) levels, enzyme preparation and their interaction on some blood characteristics of broiler chicks

\begin{tabular}{|c|c|c|c|c|c|c|c|c|c|}
\hline & $\begin{array}{l}\text { Traits } \\
\text { reatment }\end{array}$ & $\begin{array}{l}\text { RBC's } \\
\mathrm{x} 106 /\end{array}$ & $\begin{array}{l}\text { WBC's } \\
\text { x103/ }\end{array}$ & $\begin{array}{l}\text { Total Ig } \\
\text { (mg/dl) }\end{array}$ & PCV\% & Hb (g/dl) & $\underset{(\mathrm{fl})}{\operatorname{MCV} X 10-5}$ & $\begin{array}{c}\text { MCH } \\
\text { X10-5 (pg) }\end{array}$ & $\begin{array}{c}\mathrm{MCHC} \\
(\mathrm{g} / \mathrm{dl})\end{array}$ \\
\hline \multicolumn{10}{|c|}{ (A) Effect of DDGS } \\
\hline \multicolumn{2}{|r|}{$0 \%$} & $3.16^{\mathrm{b}}$ & 9.18 & $182.92^{\mathrm{d}}$ & $31.33^{\mathrm{b}}$ & $9.30^{\mathrm{c}}$ & 99.57 & $2.96^{\mathrm{b}}$ & $0.30^{\mathrm{b}}$ \\
\hline \multicolumn{2}{|r|}{$5 \%$} & $3.45^{\mathrm{a}}$ & 9.68 & $236.20^{\mathrm{b}}$ & $31.83^{\mathrm{b}}$ & $11.98^{\mathrm{b}}$ & 92.93 & $3.48^{\mathrm{a}}$ & $0.38^{\mathrm{a}}$ \\
\hline \multicolumn{2}{|r|}{$10 \%$} & $3.38^{\mathrm{ab}}$ & 9.87 & $200.23^{\mathrm{c}}$ & $31.00^{\mathrm{b}}$ & $9.41^{\mathrm{c}}$ & 91.76 & $2.79^{\mathrm{b}}$ & $0.31^{\mathrm{b}}$ \\
\hline \multicolumn{2}{|r|}{$15 \%$} & $3.62^{\mathrm{a}}$ & 9.49 & $265.45^{\mathrm{a}}$ & $34.67^{\mathrm{a}}$ & $13.19^{\mathrm{a}}$ & 97.82 & $3.64^{\mathrm{a}}$ & $0.38^{\mathrm{a}}$ \\
\hline \multicolumn{2}{|r|}{$\mathrm{SE} \pm$} & 0.09 & 0.23 & 5.22 & 0.48 & 0.29 & 2.28 & 0.09 & 0.01 \\
\hline \multicolumn{2}{|c|}{ Significant } & $*$ & N.S & $* *$ & $* *$ & $* *$ & N.S & $* *$ & $* *$ \\
\hline \multicolumn{10}{|c|}{ (B)Effect of enzyme addition } \\
\hline \multicolumn{2}{|c|}{ Without enzyme } & 3.45 & 9.4 & $202.739^{b}$ & $31.04^{\mathrm{b}}$ & $11.91^{\mathrm{a}}$ & $90.28^{\mathrm{b}}$ & $3.44^{\mathrm{a}}$ & $0.38^{\mathrm{a}}$ \\
\hline \multicolumn{2}{|c|}{ With enzyme } & 3.35 & 9.71 & $239.66^{\mathrm{a}}$ & $33.38^{\mathrm{a}}$ & $10.03^{b}$ & $99.71^{\mathrm{a}}$ & $2.99^{\mathrm{b}}$ & $0.30^{\mathrm{b}}$ \\
\hline \multicolumn{2}{|c|}{ SEM } & 0.06 & 0.15 & 3.69 & 0.34 & 0.20 & 1.61 & 0.06 & 0.01 \\
\hline \multicolumn{2}{|c|}{ Significant } & N.S & N.S & $* *$ & $* *$ & $* *$ & $* *$ & $* *$ & $* *$ \\
\hline \multicolumn{10}{|c|}{$(\mathrm{A} * \mathbf{B})$ Interaction } \\
\hline \multirow{4}{*}{ 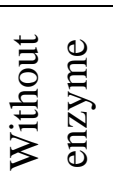 } & T1 $0 \%$ & 3.17 & $8.38^{\mathrm{d}}$ & $173.41^{\mathrm{d}}$ & $29.50 \mathrm{c}$ & $9.62^{\mathrm{c}}$ & 93.72 & $3.06^{\mathrm{cd}}$ & $0.33^{\mathrm{c}}$ \\
\hline & $\mathrm{T} 2 \quad 5 \%$ & 3.59 & $9.05^{\mathrm{c}}$ & $228.47^{\mathrm{bc}}$ & $30.33 \mathrm{c}$ & $11.98^{\mathrm{b}}$ & 85.06 & $3.35^{\mathrm{bc}}$ & $0.40^{\mathrm{ab}}$ \\
\hline & T3 $10 \%$ & 3.37 & $10.63^{\mathrm{a}}$ & $180.64^{\mathrm{d}}$ & $29.00^{\mathrm{c}}$ & $10.82^{\mathrm{bc}}$ & 86.06 & $3.21^{\mathrm{c}}$ & $0.37^{\mathrm{b}}$ \\
\hline & $\mathrm{T} 4 \quad 15 \%$ & 3.67 & $9.53^{\mathrm{bc}}$ & $228.44^{\mathrm{bc}}$ & $35.33^{\mathrm{a}}$ & $15.21^{\mathrm{a}}$ & 96.27 & $4.14^{\mathrm{a}}$ & $0.43^{\mathrm{a}}$ \\
\hline \multirow{4}{*}{ 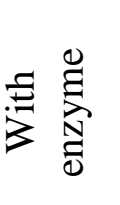 } & $\mathrm{T} 5 \quad 0 \%$ & 3.15 & $9.98^{\mathrm{b}}$ & $192.43^{\mathrm{d}}$ & $33.17^{\mathrm{ab}}$ & $8.98^{\mathrm{d}}$ & 105.41 & $2.86^{\mathrm{d}}$ & $0.27^{\mathrm{d}}$ \\
\hline & T6 $5 \%$ & 3.31 & $10.30^{\mathrm{ab}}$ & $243.94^{b}$ & $33.33^{\mathrm{ab}}$ & $11.98^{\mathrm{b}}$ & 100.81 & $3.62^{\mathrm{b}}$ & $0.36^{\mathrm{bc}}$ \\
\hline & $\mathrm{T} 7 \quad 10 \%$ & 3.39 & $9.10^{c}$ & $219.82^{c}$ & $33.00^{\mathrm{b}}$ & $7.99^{\mathrm{e}}$ & 97.46 & $2.36^{\mathrm{e}}$ & $0.24^{\mathrm{d}}$ \\
\hline & T8 $15 \%$ & 3.57 & $9.45^{\mathrm{bc}}$ & $302.46^{\mathrm{a}}$ & $34.00^{\mathrm{ab}}$ & $11.18^{\mathrm{b}}$ & 95.15 & $3.13^{\mathrm{cd}}$ & $0.32^{\mathrm{c}}$ \\
\hline \multirow{2}{*}{\multicolumn{2}{|c|}{$\begin{array}{c}\text { SEM } \\
\text { Significant }\end{array}$}} & 0.13 & $\begin{array}{c}0.31 \\
* *\end{array}$ & $\begin{array}{c}7.39 \\
* *\end{array}$ & 0.67 & 0.40 & 3.22 & $\begin{array}{c}0.13 \\
* *\end{array}$ & 0.01 \\
\hline & & N.S & $* *$ & $* *$ & & $* *$ & N.S & & $* *$ \\
\hline
\end{tabular}

a, b,c,..etc Means in each column, within each item, bearing the same superscripts are significantly different ( $p<0.05)$.N.S not significantly different ( $\mathrm{p} \geq 0.05)$. (Means \pm SEM). Avizyme 1500 enzyme at levels of 0 and $1 \mathrm{~g} / \mathrm{kg}$ diet 


\section{REFERENCES}

Barekatain, M. R.; Antipatis, C.; Rodgers, N.; Walkden-Brown, S. W.; Iji, P. A.; and Choct, M., 2013. Evaluation of high dietary inclusion of distillers dried grains with solubles and supplementation of protease and xylanase in the diets of broiler chickens under necrotic enteritis challenge. Poult. Sci.,6:1579-1594.

Batal, A. B.; and N. Dale, 2003. Mineral composition of distillers dried grains with solubles. J. Appl. Poult. Res., 12:400-403.

Campbell, T. W., 1995. Avian hematology and cytology $\left(2^{\text {nd }}\right)$. Iowa state university press, Ames, pp:104.

Chesson, A., 2001. Non-starch polysaccharide degrading enzymes in poultry diets: Influence of ingredients on the selection of activities. World's Poult. Sci. J., 57: 251-263.

Chopra, I. J.; Solomon, D. H.; and Beall, G. N., 1971. Radioimmunoassay for measurement of Triiodothyronine in human serum. J. Glin. Invest., 50: 20332041.

Cowieson, A. J.; and Ravindran, V., 2008. Effect of exogenous enzymes in maizebased diets varying in nutrient density for young broilers: growth performance and digestibility of energy minerals and amino acids. Brit. Poult. Sci., 49: 37-44.

Daice, S. J.; and Lewis, S. M., 1991. Practical Hematology, $7^{\text {th }}$ ED. Churchill Livingstone.

Doumas, B. T.; Watson, W. A.; and Biggs, H. G., 1971. Albumin standards and the measurement of serum albumin with bromcresol green. Clin Chim Acta., $1: 87-96$.

Duncan, D. B., 1955. Multiple rang and multiple f test. Biometrics, 11: 1-42. Failure of cloistral immunoglobulin transfer in calves dying from infectious disease. JAVMA. 169: 713- 718.

El-Abd; Niamat M., 2013. Evaluation of using distillers dried grains with solubles (DDGS) in Japanese quail diets. World App. Sci. J. 22: 17-21.

Fossati P.; Prencipe L., 1982. Serum triglycerides determined colorimetrically with an enzyme that produces hydrogen peroxide. Clin Chem., 10: 2077-2080.

Gornall, A. C.; Baradawill, C. J.; and David, M. M., 1949. Determination of serum proteins by means of the biuret reaction. J. Biol Chem., 177: 751-766.

Graham, H.; and Aman, P., 1991. Nutrition aspects of dietary fibres. Animal Feed Science and Technology, 32:143-158.

Konuk, T., 1975. Pratik Fizyoloji-I. Ankara: Ankara University Veteriner Fakultesi, A. U. Basimevi, And No: 314.

Lesson, S.; and J. D. Summers, 2005. Commercial Poultry Nutrition3rd edition published by University Books P.O. Box 1326. Guelph, Ontario, Canada, NIH 6N8. P: 92.

Liu, N.; Ru, Y. J.; Cowieson, A. J.; Li, F. D.; and Cheng, X. C. H., 2008. Effects of phytate and phytase on the performance and immune function of broilers fed nutritionally marginal diets. Poultry Science. 87: 1105-1111.

Makled, M. N.; M. A. Metwally; I. A. Soliman; and H. A. Younis, 2005. Impact of different levels of dietary multienzymes supplement on California rabbit performance $3^{\text {rd }}$. International poultry conference 4-7 Apr. HurghadaEgypt.

Mcewan, A. D.; E. W. Fisher; I. E. Selman; and W. J. Penhale, 1970. Aturbidity test for the estimation of immunoglobulin levels in neonatal calf serum. Cli. Chime. Acta. 27: 155-163. 
Meguire, T. C.; N. E. Pfeiffer; J. M. Weikel; and R. C. Bartsch, 1976.

Noll, S.L.;C. Abe; and J. Brannon, 2003. Nutrient composition of corn distiller dried grains with soluble. Poultry Science. 82(Suppl.1):71.

NRC (National research council) 1994. Nutrient Requirements of Poultry, 9th ed. Washington, DC: National. Academies Press.

Olentine, C., 1986. Ingredient profile: Distillers feeds. Proc. Distillers Feed Conf. 41:13-24.

Pfeiffer, N. E.; T. C. McGuirn; R.B. Bendel; and J. M. Weikel, 1977. Quantitation of bovine immunoglobulins: comparison of single radial immunodiffusion, zinc sulfate turbidity, serum electrophoresis, and refractometer methods. Am J Vet Res. 5: 693-698.

Ragy Abdo Shedeed Abd El-fatah, 2013. Incorporating of dried distillers grains (DDGS) in quail diets under desert environmental conditions. MS. C. Thesis. menufyia university, El- Sadat Branch, Munufyia province, Egypt.

Trinder P., 1969. Determination of glucose in blood using glucose oxidase with an

Wang, Z.; S. Cerrate; C. Coto; F. Yan; and P.W. Waldroup, 2007. Effect of Rapid and Multiple Changes in Level of Distillers Dried Grain with Solubles

Yahav, S.; D. Lugar; A. Cahaner; M. Dotan; M. Ruzan ; and S. Hurwitz, 1998. Thermoregulation in naked neck

Yassein S. A.; A.T., El-yamny; and G. M., El-mallah, 2004. Barley as replacement for yellow corn with or without enzyme or DL-methionine in practical diets of growing turkeys. Egypt Poultry Science. 24 (4): 929-944.

Young, DS., 2001. Effects of disease onclinical Lab. Tests, $4^{\text {th }}$ ed. AACC Press, spinreact@spinreact.com.
Rajgude, D.R; V.P. Pathak; R.S. Ingole; and M.V. Joshi, 2005. Biochemical alterations in the blood in experimental hypothyroidism in broilers. Indian Vet. J., (82): 1145-1148.

Reitman, S.; and S. Frankel, 1957. A colorimetric method for the determination of serum glutamic oxalacetic and glutamic pyruvic transaminases. Amer. J. Clin. Path., 28: 56-63.

Renewable Fuels Association, 2005. Homegrown for the homeland: Ethanol industry outlook. http://www.ethanolrfa. Orglobjects/pdf/outlookoutlook_2005.p df.

S.A.S. Institute 2003. SAS User's Guide: Statistics. SA Institute, Cary, NC.

Shalash, S. M. M.; M.N. Ali; M.A. M. Sayed; Hoda E. EI-Gabry ; and M. Shabaan, 2009. Novel method for improving the utilization of corn dried distiller's grains with soluble in broiler diets. International Journal of Poultry Science. 8 (6): 545-552.

alternative oxygen receptor. Ann. Clin. Biochem., 6: 24-27.

(DDGS) in Broiler Diets on Performance and Carcass Characteristics. International Journal of Poultry Science. 6 (10): 725-731.

chickens subjected to different ambient temperatures. British Poultry Science. (39): 133-138.

Youssef, Amani A.W.; N.A. Abd ElAzeem; E.F. El-Daly; and M.M. ElMonairy, 2013. The impact of feeding graded levels of distillers dried grains with soluble (DDGS) on broiler performance, hematological and histological parameters. Asian Journal of Poultry Science. 7 (2): 41-54. 
Yukio Akiba;L. S. Jensen; C. R. Barb; and R. R. Kraaling, 1982. Plasma estradici, thyroid hormones, and liver lipid content in laying hens fed different isocaloricdiets. The journal of nutrition. J. Nutr., 112: 299-308.

Zhang Shi-yuan; Zhou Lian-gao; WU Rong-rong; Zhong Wei-fang, 2009. Effects of DDGS on growth performances and blood thyroid hormones in Cherry Valley Duck. Animal Husbandry \& Veterinary Medicine. Abs., 834.
Zollner, N.; and K. Kirsch, 1962. Test combination of the total lipids. Z Ges Exp. Med. 135: 545-561.

Zou1, X. T.; X. J. Qiao; and Z. R. Xu, 2006. Effect of $\beta$-mannanase (hemicell) on growth performance and immunity of broilers. Poultry Science. 85: 2176-2179

Zeweil, H. S.; Salaw, G. K. Genedy; and N.S. Isshak, 2005. Effect of rice bran and enzyme mixture supplementation on performance, digestibility and carcass traits of growing Japanese quail. Egypt Poultry Science. 25(2): 225-240. 
الملخص العربى

\section{تأثثر استخدام مخلفات التقطير الحيوي للحبوب وانزيم الافازيم فى علائق كتاكيت التسمين علي

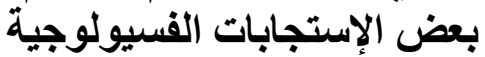

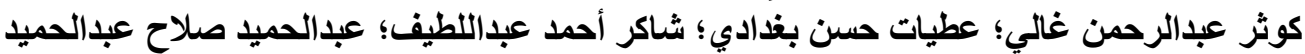

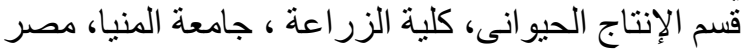

إستهدفت هذه التجربة در اسة إحلال مخلفات التقطير الحيوي للحبوب من فول الصويا و الذرة مستويات (صفر ، 5، 10؛

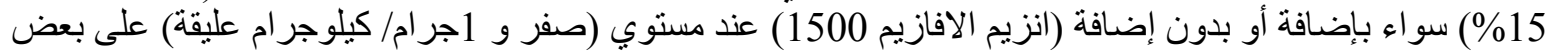

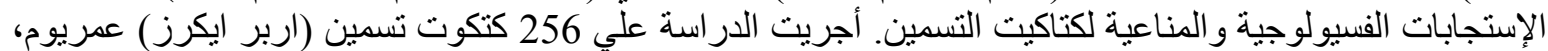

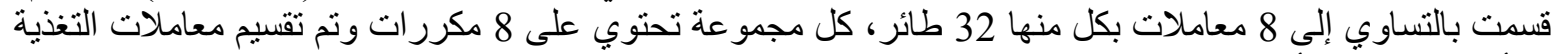

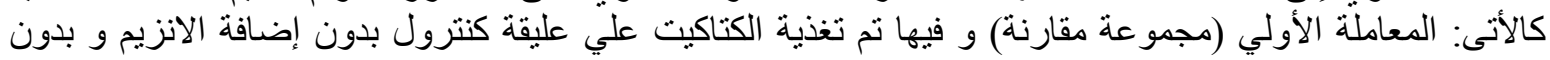

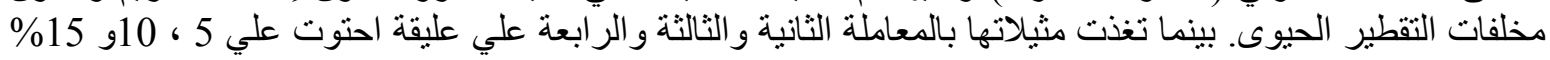

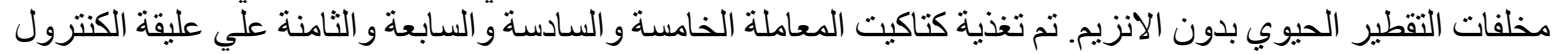

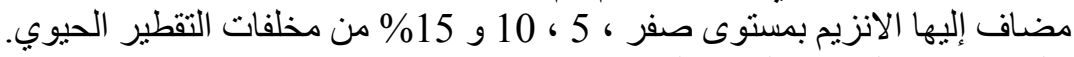
خلصت نتائج الار اسة إلي ما يلي: الطئي:

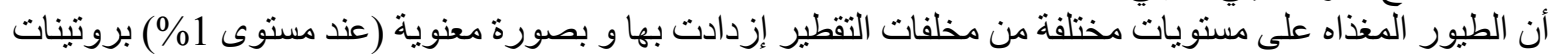

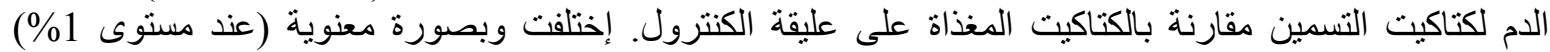

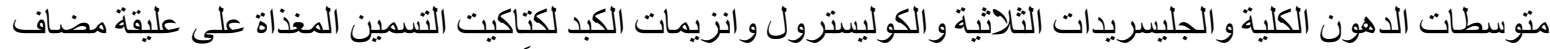

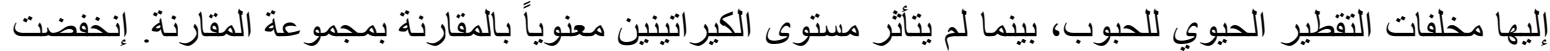

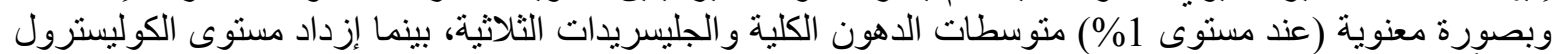

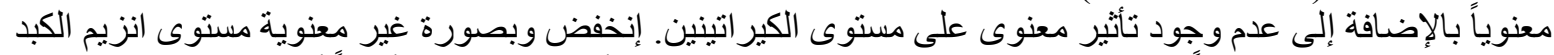

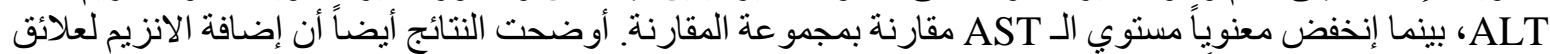

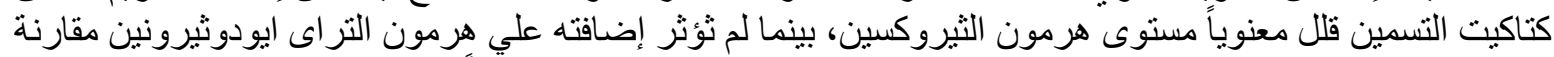

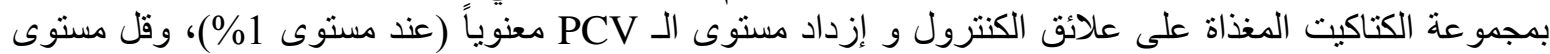

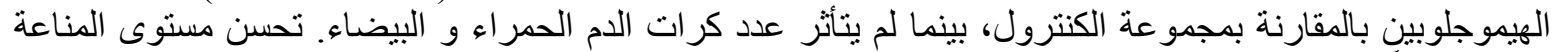

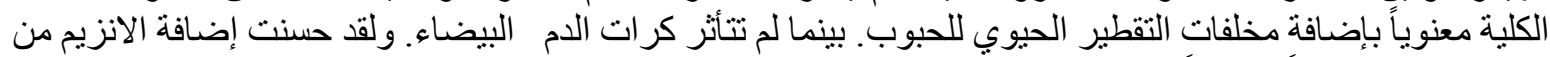

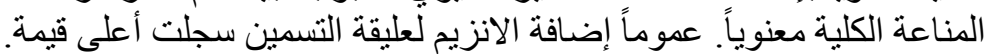

